\title{
On Money and Output: Is Money Redundant?
}

\author{
R.W. Hafer \\ Southern Illinois University Edwardsville \\ Joseph H. Haslag ${ }^{*}$ \\ University of Missouri-Columbia \\ Garett Jones \\ Southern Illinois University Edwardsville
}

\begin{abstract}
There is an emerging consensus that money can be largely ignored in making monetary policy decisions. Rudebusch and Svensson $(1999,2002)$ provide some empirical support for this view. In this paper, we reconsider the role of money. We find that money is not redundant. More specifically, there is a significant statistical relationship between lagged values of money and the output gap, even when lagged values of real interest rates and lagged values of the output gap are accounted for. We further test for and find significant information useful in predicting movements in the output gap arise from movements in both inside and outside money.
\end{abstract}

\footnotetext{
* Corresponding author: Joseph H. Haslag, Department of Economics, 118 Professional BLDG, University of Missouri-Columbia, Columbia, MO 65211. Phone: 573-882-3483, Fax: 573-882-2697, email: haslagj@missouri.edu. An earlier version of this paper was presented at the Missouri Economics Conference. We would like to thank session participants for their comments, especially Sharon Kozicki and Bob Rasche. We also would like to thank Bennett McCallum, Charles Plosser and an anonymous referee for suggestions on an earlier version. The views expressed are the authors'.
} 


\section{INTRODUCTION}

There is widespread agreement that the Federal Reserve targets the federal funds rate to achieve its policy objectives. Indeed, most central banks today use some interest rate as the policy instrument. What continues to be debated, however, is whether monetary aggregates have any role to play in modern monetary policy.

The emerging consensus appears to be that money can be largely ignored both in the analysis of the macroeconomy as well as in the formation of monetary policy. On the theoretical side, Taylor-like policy rules model the interest rate as determined by movements in the output gap and inflation: monetary aggregates play no direct function in the formulation of policy in such a setup. Empirically, the findings of Rudebusch and Svensson $(1999,2002)$ are often cited as evidence supporting such a money-free model, especially for the United States. More precisely, their empirical results indicate (1) that there is a systematic, inverse relationship between the real rate of interest and output; (2) that monetary aggregates are not important for understanding the effect of monetary policy actions; (3) that a simple backward-looking model is a good representation of U. S. output; and (4) that this model is useful for conducting optimal monetary policy experiments. ${ }^{1}$

In this paper, we reexamine the role of money in terms of its relationship to future movements in output at business-cycle frequencies. Insofar as the money-output relationship is central to the notion that money is useful as a policy indicator, our

\footnotetext{
${ }^{1}$ Sims (1980) long ago demonstrated the two empirical regularities that serve as the foundation for this viewpoint: in output regressions in which both real interest rates and monetary aggregates are included as right-hand-side variables, movements in output were systematically related to innovations in real interest rates and not to such changes in monetary measures. More recently, Fuhrer and Moore (1995), Kerr and
} 
evidence bears directly on points (1) and (2) above. In other words, if changes in money are systematically related to future changes in the output gap, then money contains useful information that helps to predict future movements in output. Such evidence further suggests that the popular backward-looking model may have to be amended with respect to points (3) and (4).

The empirical specification used here is a modified version of the regression estimated in Rudebusch-Svensson (2002). ${ }^{2}$ Money was noticeably absent from their regressions. Our goal is to determine the relative roles of interest rates and money in predicting movements in the output gap for the United States over the period since 1960. A key result is that we find a statistically significant relationship between movements in lagged money, especially M2, and the output gap even after the effects of lagged gap and the real federal funds rate are accounted for. Since a recurring theme in work such as this is how money is measured, we tested for and find that significant information useful in predicting movements of the output gap arise from movements in both inside and outside money. ${ }^{3}$ Overall, our evidence indicates that researchers and policy makers should not be so quick to dismiss the importance of money. ${ }^{4}$

\footnotetext{
King (1996), McCallum and Nelson (1999), Rudebusch and Svensson (2002) and Nelson (2003), among others, contribute to this extensive literature.

${ }^{2}$ An alternative approach would be to estimate a VAR model that includes money and interest rates, in various configurations, as policy measures. A recent example of this approach is Leeper and Roush (2003). Evidence gathered from each approach should be viewed as complementary, not substitutes. ${ }^{3}$ Our findings corroborate the results presented in Leeper and Roush (2003) who argue that it matters how money is measured. The critical feature is the identification scheme; under some identifying assumptions, money is not important, while it is very important under other identifying assumptions. See also, Meltzer (1999) and Nelson (2002) for specifications in which movements in money and output are systematically related.

${ }^{4}$ Unlike the Federal Reserve, the European Central Bank considers money as a key variable in its policy strategy. See European Central Bank (2003) for details.
} 
The paper is organized as follows. Section 2 provides a brief discussion of the theoretical model from which the estimated equation (output gap as a function of past gap and the real federal funds rate) is taken. Section 3 re-examines on several fronts the regression results and tests the significance of money as an additional predictor of future output movements. Section 4 offers some brief comments and observations.

\section{THE MODEL}

In many theoretical models of monetary policy, money is superfluous: monetary policy is defined as setting some short-term interest rate which then drives output and, over time, inflation. Money is redundant in such a model, because the money supply is demand determined (i.e., infinitely elastic). Because this model is described in numerous other papers, only a brief description is provided here. ${ }^{5}$

The model is described by three equations: an aggregate demand equation, a Phillips-type curve equation and a policy rule. A representative version of this dynamic model may be written as

$$
\begin{aligned}
& y_{g t}=a y_{g t-1}+b E_{t}\left(y_{g t+1}\right)-c\left[R_{t}-E_{t}\left(p_{t+1}\right)\right]+e_{1 t} \\
& p_{t}=d\left(y_{g t}\right)+w_{1} p_{t-1}+w_{2} E_{t}\left(p_{t+1}\right)+e_{2 t} \\
& R_{t}=r^{*}+E_{t}\left(p_{t+1}\right)+f y_{g t-1}+g\left(p_{t-1}-p^{T}\right)
\end{aligned}
$$

where $\mathrm{y}_{\mathrm{gt}}$ is the output gap, measured as the deviation of real output from its potential, $\mathrm{R}$ is the nominal rate of interest, $p$ is the rate of inflation, $r^{*}$ is the equilibrium real rate of interest, and $\mathrm{p}^{\mathrm{T}}$ is the central banker's target rate of inflation. The terms $\mathrm{e}_{1}$ and $\mathrm{e}_{2}$ are

\footnotetext{
${ }^{5}$ This version, taken from Meyer (2001), is representative of the models found in, among others, Fuher and Moore (1995), Clarida et al. (1999) or McCallum and Nelson (2000).
} 
stochastic shocks, and the coefficients $\mathrm{w}_{1}$ and $\mathrm{w}_{2}$ sum to unity to ensure that stability conditions for the system of first-order linear stochastic equations are satisfied.

Equation (1) is a forward-looking IS equation in which the output gap is dependent on future output as well as the real rate of interest. Equation (2) is an expectations augmented Phillips curve that provides price stickiness in the model. The Phillips Curve helps generate the lagged response of the economy to policy changes coming from equation (3), a now-standard Taylor rule in which the interest rate is the central bank's policy instrument.

Notably, this model eliminates the LM function describing equilibrium in the money market and replaces it with a description of how policymakers establish the equilibrium interest rate. Policy actions adjust the money supply, given money demand conditions, to achieve an interest rate that satisfies the conditions laid out in equation (3). If the rate of interest is determined according to equation (3), the money supply must change to accommodate changes in money demand. ${ }^{6}$ The upshot is that money plays no direct role in determining the path of output or inflation. Instead, the policy transmission mechanism runs from policy actions that move the short-term real rate of interest that in turn affects the output gap that influences inflation over time. The assumed short-term rigidities in the model ensure that a change in the reserve position of the banking system impacts short-term real interest rates.

For this model to serve as a useful policy guide, it is necessary to establish the empirical link between interest rates, money, and economic outcomes. Our aim is to determine if there is a direct effect of monetary aggregates on the output gap independent

\footnotetext{
${ }^{6}$ See, for example, Rotemberg and Woodford (1997).
} 
of movements in real interest rates. Consequently, we follow previous research and estimate an empirical version of equation (1). ${ }^{7}$

As a point of reference consider an estimate of equation (1) reported by Rudebusch and Svensson (2002). ${ }^{8}$ Throughout our analysis, we use quarterly observations of the output gap, the quarterly average of nominal federal funds rate, inflation measured by the GDP chain-weighted index. Their results using U.S. data for 1961-1996 are (tstatistics in parentheses):

$$
\begin{aligned}
& \mathrm{y}_{\mathrm{gt}+1}=\underset{(14.70)}{1.161 \mathrm{y}_{\mathrm{gt}}-.259} \mathrm{y}_{\mathrm{gt}-1}-.088\left(\mathrm{i}-\mathrm{p}_{\mathrm{t}}\right) \\
& \mathrm{R}^{2}=.90 ; \mathrm{SE}=.823 ; \mathrm{DW}=2.08
\end{aligned}
$$

where the output gap is measured as the percentage difference between actual real GDP and the Congressional Budget Office's (CBO) measure of potential real GDP, $i$ is a fourquarter average of the quarterly average of the federal funds rate, and $\mathrm{p}_{\mathrm{t}}$ is the four-quarter average rate of inflation using the GDP chain weighted index. ${ }^{9}$ The variables are measured as deviations from their mean values before estimation; hence the omission of a constant term.

Rudebusch-Svensson (2002) report that the estimated relation is stable across 1961-96 and that "lags of money (in levels or growth rates) were invariably insignificant when added" to equation (1). ${ }^{10}$ This outcome suggests that one could (and they do)

\footnotetext{
${ }^{7}$ Although it appears as a structural equation in the model, our estimation is more akin to the kind of reduced-form empirical tests so popular in the long history of this debate.

${ }^{8}$ Comparative estimates for the U.S. are provided by Rudebusch and Svensson (2002) and Nelson (2002); and for the United Kingdom, Nelson (2002).

${ }^{9}$ See Rudebusch and Svensson (2002) for more discussion of the construction of the variables.

${ }^{10}$ Gerlach and Smets (1995) also find that adding M2 or M3 to a three-variable VAR model consisting of output, inflation and a nominal interest rate, does not improve the model's explanatory power when estimated for each of the G-7 countries. The fact that simple VAR models reject the importance of money may stem from the stationarity assumptions imposed on the data. (See Hafer and Kutan 1998)
} 
dismiss the usefulness of monetary aggregates in helping to predict future movements in the output gap. Still, several rationales can be offered for why money should be considered. For example, a persistent increase in real money balances will push down long-term interest rates. Nelson (2002) argues that movements in real balances are informative since an observed rise in real money precedes a fall in the imperfectlyobservable (but extremely important) long-term real interest rate. Meltzer (1999) contends that changes in the money supply adjust short-term real interest rates (assuming sticky prices), impacting the banking system's balance sheet. If money supply changes are redundant, and since interest rates are affected by more than monetary policy actions alone, movements in monetary aggregates could affect aggregate demand independent of the real interest rate. Indeed, Nelson (2002) estimates a version of equation (1) for the U.S. and the U.K. and finds that lagged values of the real monetary base are significant when included with the real interest rate as an explanatory variable.

\section{ANOTHER LOOK AT THE RESULTS}

In this section we reexamine the role of the real rate of interest and money in determining movements in the U.S. output gap. Our regression, like our predecessors', is backward-looking: the output gap is explained by lagged values of gap, interest rates and money. Our sample period extends that of Rudebusch and Svensson slightly, running through 2000. We focus on two basic questions. First, is money important to understanding future movements in the output gap? Second, are the results stable over time? 


\subsection{Estimates of the Basic Model}

Table 1 presents our estimates of equation (1). The variables are constructed as in Rudebusch and Svensson (2002) and Nelson (2002). ${ }^{11}$ As a check, column (1) presents the results that we will henceforth refer to as the "baseline" estimate since it is most closely associated with equation (1). Note that it does not include money. For comparison purposes, we use the same sample period as Rudebusch and Svensson. ${ }^{12}$ The sign, magnitude and statistical significance of the estimated coefficients are quite comparable to those reported earlier in the text [see equation (4)]. Even after accounting for prior movements in the gap, changes in the real federal funds rate have a statistically significant, negative affect on the gap.

The results reported in column (2) of the table extend the sample through 2000. Using the extended sample (and eschewing demeaning of the variables) the estimates again are almost identical to those based on 1961-1996 data. Specifically, the estimated coefficients are quite similar in size and significance, as is the comparability of the summary statistics. The evidence thus suggests that extending the sample to the end of the expansion does not materially affect the parameter estimates. ${ }^{13}$

\footnotetext{
${ }^{11}$ Data for the federal funds rate and the GDP chain-weighted price index are taken from the Federal Reserve Bank of St. Louis's FRED data base; the gap measure is measured using the CBO potential output series. In an earlier version of the paper we estimated this and the other regressions reported below using a gap variable derived from a Hodrick-Prescott potential output series. The results using the HP gap are consistent with those reported in the text and are not, therefore, reported. They are available upon request. ${ }^{12}$ Note also in this version we demean the data before estimation; hence the omission of a constant term.

${ }^{13}$ A number of papers compare and contrast alternative measures of potential output and how these different measures can impact policy decision. A representative collection of such work is de Brouwer (1998), Clarida, et al (2000), Claus, et al (2000), Haltmaier (2001) and the CBO (2001). Neiss and Nelson (2002) provide a useful discussion of measuring the output gap as it relates to predicting inflation within the framework of a New Keynesian Phillips curve. Overall, using a gap measure based on a Hodrick-Prescott (1997) filter for potential real GDP delivers the same qualitative story: changes in the lagged values of the real interest rate measures are significantly related to the output gap.
} 
To consider the overall stability of the estimated equations we calculated standard F-statistics using 1982.4 as the hypothesized break point. ${ }^{14}$ Reported in the row denoted "F(pr)" in Table 1, the F-test results using 1961-1996 data indicate that we cannot reject stability, at least not at the 10 percent level. When the extended 1961-2000 sample is used, however, parameter stability is rejected easily $(\mathrm{pr}<5 \%)$. We further examine this apparent instability by estimating the baseline model for the two sub-periods, 1961-1982 and 1983-2000. These results, reported in the two right-hand columns of Table 1, are striking. The sub-period estimates reveal that the real rate of interest has no statistically significant predictive power in the post-1982 sample. Not only is the estimated coefficient insignificant at any reasonable level, but it is changes sign. The empirical importance of the real federal funds rate in the full sample period may stem from its correlation with the gap during 1961-1982, but not since. The ability to empirically pin down this part of the policy transmission mechanism is thus questionable.

Temporal instability is important for at least one of the four themes identified in the introduction of this paper. As noted above, a key point that Rudebusch and Svensson make is that this backward-looking model is useful for conducting policy experiments. Because we find evidence that the model is temporally unstable, we infer that using the model to conduct policy experiments is at least questionable and may be compromised.

\footnotetext{
${ }^{14}$ Leeper and Roush (2003) use the same break point based on evidence from previous work examining the stability of monetary policy [e.g., Bernanke and Milhov (1998), Clarida, et al. (2000) and Hetzel (2000)]. The break could be treated as a random variable. The 1982 break point coincides with several pertinent factors; for instance, the velocities of some monetary aggregates began to shift dramatically about that time
} 


\subsection{Does Money Matter?}

We address the question of money's importance by adding alternative measures of money in the baseline model. Earlier work [e.g., Rudebusch and Svensson (2002) and Nelson (2002)] considers the empirical role of real money balances by augmenting the regression with lagged values of real money balances. Consistent with earlier studies and the measurement of the real rate of interest, the money variable is calculated as the percentage annual change in real money balances (nominal money deflated by the GDP chain-weighted index). We use one-quarter lagged values of the real-money balance measure in the specifications. To glean from the data evidence about which money measure is preferable, three standard measures of money are used: the adjusted monetary base, M1 and M2. ${ }^{15}$ As with the baseline regressions, we use quarterly observations spanning the period 1961 through 2000.

Table 2 presents estimates of the baseline model with money added. We report the regressions in pairs: in each pair, the left-hand column under each money measure uses data for the full 1961-2000 sample. The results all reveal that, statistically speaking, money matters. When included along with the real rate of interest, the monetary base, M1 and M2 all have a significant ( $\mathrm{pr}<5 \%$ ), positive coefficients in the output gap regressions. Contrary to some previous results, both theoretical and empirical, our regressions do not support the omission of monetary aggregates.

and this is generally recognized as the time when the Federal Reserve reverted to a policy of focusing on controlling the federal funds rate and not the monetary aggregates.

${ }^{15}$ The nominal money measures are taken from the St. Louis Fed's data base FRED. We use the quarterly average value reported for each money measure. The adjusted monetary base is computed by the Federal Reserve Bank of St. Louis and combines high-powered money with a reserve adjustment magnitude. 
We again assess the temporal stability of models in which a monetary measure is included. At the bottom of each column is the significance level of an F-statistic based on testing for a 1982:Q4 break. (See footnote 14.) In each pair of regressions that we estimate, we conserve space by reporting the results for the 1983-2000 period in the lefthand column under each monetary variable. Like the baseline equation, we find that the null of stability is rejected for each equation at the 10 percent level, although stability cannot be rejected at the five percent level for the monetary base and M2 equations.

In the breakdown of the sample periods, several results are worth noting. Recall that when estimated over 1983-2000 sample, the real rate of interest became statistically insignificant in the baseline regression. When paired with the monetary base or M1 we again find that the real rate of interest has no statistically significant affect on real output using the recent data. We also find that the coefficients on the monetary base and M1 do not achieve significance for the more recent data. Not only are the estimated coefficients on these monetary aggregates insignificant over 1983-2000, but the sign on M1 flips to negative. In contrast, the results for $\mathrm{M} 2$, found in the final column of Table 2, indicate that movements in lagged values of real M2 continue to be systematically related to movements in the output gap during the recent subperiod. The evidence suggests that information unique to a broader measure like M2 is important for understanding money and its relationship to output. ${ }^{16}$

\footnotetext{
${ }^{16}$ It should be noted that when paired with M2, the estimated coefficient on the real rate of interest is negative and statistically significant in the 1983-2000 sample. This is evidence that when money is omitted from a business-cycle model, the model is likely to misspecified. In this vein, Leeper and Roush (2003) show that in a VAR model, an interest rate shock's effect on output increases substantially when M2 is included.
} 
The upshot of the results in Table 2 is that when paired together the real rate of interest and M2 can provide statistically significant information about future output gap changes. This cannot be said for other money measures or the real rate alone. We thus interpret the evidence as suggesting that it is unwise to ignore M2, either in these backward-looking specifications, or in the setting of policy.

\subsection{Inside or Outside Money?}

Because the evidence points to an important predictive role for a broad monetary aggregate, an interesting though often ignored question is whether there something inherent to M2 that is systematically related to output. That is, does the outcome for M2 derive from a special relation between inside money and outside money and the gap? The answer is not obvious and can be easily tested. ${ }^{17}$

To address this question, we decompose M2 into its outside money (the monetary base) and inside money (the money multiplier) components, adding each component separately to the baseline equation. The results for this expanded regression are reported in the two right-hand columns in Table 2 under the M2 multipler/Base heading. We estimate the equation for the full sample period, 1961 through 2000, and also for the subsample spanning 1983-2000. The coefficient on the monetary base measure is reported in the row labeled $\mathrm{M}(-1)$ and the coefficient on the money multiplier is reported in the row labeled $\mathrm{mm}(-1)$.

The results of this exercise are informative on several counts. First, the estimated coefficients on the monetary base (M) and the M2 multiplier (mm) are correctly signed

\footnotetext{
${ }^{17}$ An early attempt to address this aspect of money's importance is Gordon (1985). We also estimated the relation using M1 and found that the base component is significant for the full period but not the post-1982
} 
and highly significant. Second, the estimates suggest that the impact of a change in the monetary base and the multiplier are not different. Indeed, a Wald test does not reject this hypothesis at the 11 percent level of significance. Third, the estimated coefficient on the real rate of interest is again negative and statistically significant. ${ }^{18}$ Finally and importantly, we are unable to reject the hypothesis of stability for the above regression. Using 1982.4 as the break point, the calculated F-statistic is significant at only the $17 \%$ level.

Thus, for the M2 multiplier/Base representation, the results indicate that one cannot reject the existence of a systematic, stable relationship between the output gap, the real rate of interest and lagged values of base money and the M2 money multiplier for the 1961-2000 period.

Compare this to our earlier finding that stability can be accepted at the five percent level when either M2 or base money are included as monetary measures (recall that stability was decisively rejected for M1). Since our M2 multiplier/Base representation implicitly contains measures of both Base and M2, the results containing Base alone or M2 alone can be interpreted as nested regressions within the broader M2 multiplier/Base representation.

The Base-only model would then be equivalent to restricting the multiplier coefficient to equal zero, while the M2 model would be equivalent to restricting the multiplier coefficient to equal the base coefficient. Between these two money measures--

period and that the M1 multiplier never achieves statistical significance. These results are available upon request.

${ }^{18}$ Freeman and Huffman (1991) show that inside and outside money are meaningfully different and can have different impacts. For instance, reductions in the cost of banking can result in higher real returns paid 
Base and M2--which model do the data prefer for predicting future output? The answer is unambiguous: The multiplier's large t-statistics eliminate the first option, but as noted above, a Wald test does not reject the second option. Thus, for researchers and policy makers seeking a monetary indicator that has a stable relationship with output, M2 appears to be the better money measure.

\section{CONCLUSIONS}

We offer evidence that omitting money from empirical business-cycle models is not without its costs. Consistent with a growing body of work, we find that movements in M2 are significantly related to changes in the output gap independent of the real federal funds rate. Indeed, our M2/real rate models have a more stable relationship with output than the real rate model preferred by Rudebusch and Svennson $(1999,2002)$. In particular, our M2/real rate models are correctly signed, even in the post-1983 period, a feature that the rate-only model lacks.

Our results offer further evidence dealing with the important and persistent question of the relationship between money, interest rates and output. In the spirit of Leeper and Roush's (2003) admonition that how money is measured is important, our results indicate that models with M2 fit the data better than models using either the monetary base or M1. Further, we note that decomposing M2 into its monetary base and multiplier components shows that both significantly predict movements in the output gap. It thus appears that both inside and outside money are important monetary indicators, a question we hope to see explored in future research.

on deposits and increase future output. In their model economy, inside money is positively related to 
Overall, these results strongly support the belief that the behavior of the money stock plays a significant role in explaining economic activity and that the real interest rate is not the only useful indicator of monetary policy. It would appear that calls for empirical monetary models without money are, at best, premature. 


\section{References}

Clarida, R., J. Gordi and M. Gertler, 1999. "The Science of Monetary Policy: A New Keynesian Perspective,” Journal of Economic Literature, 37, 1661-1707.

Claus, I., P. Conway and A. Scott, 2000. "The Output Gap: Measurement, Comparisons and Assessment," Reserve Bank of New Zealand Research Paper No. 44 (June).

Bernanke, B.S. and I. Milhoiv, 1998. "Measuring Monetary Policy," Quarterly Journal of Economics, 113, 869-902.

Congressional Budget Office, 2001. “CBO's Method for Estimating Potential Output: An Update," August.

DeBrouwer, G. 1998. "Estimating Output Gaps," Reserve Bank of Australia Research Discussion Paper 9809 (August).

European Central Bank. 2003. Overview of the Background Studies for the Reflections of the ECB's Monetary Policy Strategy. Frankfurt, Germany: European Central Bank.

Freeman, S. and Huffman, G. 1991. "Inside Money, Outside Money, and Causality," International Economic Review 32, 645-67.

Fuhrer J.C., Moore G.R., 1995. "Monetary Policy Trade-offs and the Correlation Between Nominal Interest Rates and Real Output," American Economic Review 85, 219-39.

Gerlach S. and Smets F. 1999, "Output Gaps and Monetary Policy in the EMU Area," European Economic Review, 43, 801-12.

Gordon, R.J. 1985. "The Conduct of Monetary Policy," in A. Ando, et. al eds., Monetary Policy in Our Times, MIT Press, Cambridge, 45-82.

Hafer, R.W. and A.M. Kutan. 1998. "More Evidence on the Money-Output Relationship," Economic Inquiry 35, 48-58.

Haltmaier, J. 2001. "The Use of Cyclical Indicators in Estimating the Output Gap in Japan," Board of Governors International Finance Discussion Paper NO. 701 (April).

Hetzel. "The Taylor Rule: Is It a Useful Guide to Understanding Monetary Policy?" Federal Reserve Bank of Richmond Economic Quarterly Vol. 86/2 Spring 2000, 1-33.

Hodrick, R.J. and E.C.Prescott, 1997. "Postwar U.S. Business Cycles: An Empirical Investigation," Journal of Money Credit and Banking 29, 1-16. 
Kerr, W., King, R.G., 1996. “Limits on Interest Rate Rules in the IS Model,” Federal Reserve Bank of Richmond Economic Quarterly 82, 47-75.

Leeper, E. M. and J. E. Roush, 2003. "Putting 'M' back into Monetary Policy," Journal of Money, Credit, and Banking, 35, 1217-1256.

McCallum, B.T., Nelson, E., 1999. “An Optimizing IS-LM Specification for Monetary Policy and Business Cycle Analysis," Journal of Money, Credit, and Banking 31, 296316.

Meyer, L. H., 2001. “Does Money Matter?” Federal Reserve Bank of St. Louis Review, September/October, 1-15.

Meltzer, A.H., 2001. "The Transmisson Process," in Deutsche Bundesbank ed., The Monetary Transmission Process: Recent Developments and Lessons for Europe.

Palgrave, London, pp. 112-30.

Neiss, K.S. and Nelson, E., 2003. "The Real Interest Rate Gap as an Inflation Indicator," Macroeconomic Dynamics 7(2), 239-262.

Nelson, E., 2002. "Direct Effects of Base Money on Aggregate Demand: Theory and Evidence," Journal of Monetary Economics 49(4), 687-708.

Nelson, E., 2003. "The Future of Monetary Aggregates in Monetary Policy Analysis," Journal of Monetary Economics 50(5): 1029-59.

Rotemberg, J.J., and M. Woodford, 1997. “An Optimization-Based Econometric Framework for the Evaluation of Monetary Policy." In NBER Macroeconomics Annual 1997, Bernanke, B.S. and J.J. Rotemberg, eds. MIT Press, Cambridge, 297-346.

Rudebusch, G.D., Svensson, L.E.O., 1999. "Policy Rules and Inflation Targeting," in Taylor, J.B. ed., Monetary Policy Rules. University of Chicago Press, Chicago, 203-46.

Rudebusch, G.D., Svensson, L.E.O., 2002. "Eurosystem Monetary Targeting: Lessons from US Data," European Economic Review 46, 417-42.

Sims, C. 1980. "Comparison of Interwar and Postwar Business Cycles: Monetarism Reconsidered," The American Economic Review, Vol. 70, No. 2, 250-257. 
Table 1

Estimates of Baseline Model: Various Sample Periods

\section{Replication results ${ }^{1}$}

Ours Full Subperiod results

\begin{tabular}{|c|c|c|c|c|}
\hline Variable $^{2}$ & $\underline{1961-1996}$ & $\underline{1961-2000}$ & $\underline{1961-1982}$ & 1983-2000 \\
\hline $\operatorname{GAP}(-1)$ & $\begin{array}{l}1.177 \\
(15.09)\end{array}$ & $\begin{array}{l}1.177 \\
(15.74)\end{array}$ & $\begin{array}{l}1.083 \\
(10.50)\end{array}$ & $\begin{array}{l}1.195 \\
(10.84)\end{array}$ \\
\hline $\operatorname{GAP}(-2)$ & $\begin{array}{l}-.269 \\
(3.49)\end{array}$ & $\begin{array}{l}-.261 \\
(3.53)\end{array}$ & $\begin{array}{l}-.153 \\
(1.46)\end{array}$ & $\begin{array}{l}-.295 \\
(2.80)\end{array}$ \\
\hline Real rate(-1) & $\begin{array}{l}-.085 \\
(2.74)\end{array}$ & $\begin{array}{l}-.077 \\
(2.57)\end{array}$ & $\begin{array}{l}-.174 \\
(3.45)\end{array}$ & $\begin{array}{l}.012 \\
(.32)\end{array}$ \\
\hline Constant & NA & $\begin{array}{l}.002 \\
(2.12)\end{array}$ & $\begin{array}{l}.003 \\
(2.10)\end{array}$ & $\begin{array}{l}-.0003 \\
(0.20)\end{array}$ \\
\hline$\overline{\mathrm{R}}^{2}$ & .91 & .91 & .910 & .94 \\
\hline $\mathrm{SE}$ & .008 & .008 & .009 & .005 \\
\hline DW & 2.10 & 2.09 & 2.03 & 2.20 \\
\hline $\mathrm{F}(\mathrm{pr})^{3}$ & .101 & .039 & & \\
\hline
\end{tabular}

1. These estimates use the $\mathrm{CBO}$ gap measure. Absolute value of $\mathrm{t}$-statistics appear in parentheses.

2. Variables are defined in text.

3. Probabilities for F-statistic based on 1982/IV break. 
Table 2

Estimations Results with Money ${ }^{1}$

\section{Monetary Aggregate/Sample Period}

\begin{tabular}{|c|c|c|c|c|c|c|c|c|}
\hline \multirow[b]{2}{*}{ Variable } & \multicolumn{2}{|c|}{ MB } & \multicolumn{2}{|c|}{ M1 } & \multicolumn{2}{|c|}{ M2 } & \multicolumn{2}{|c|}{ M2 multiplier/Base } \\
\hline & $\underline{1961-2000}$ & $83-2000$ & $\underline{1961-2000}$ & $1983-2000$ & $\underline{1961-2000}$ & $1983-2000$ & $1961-2000$ & $1983-2000$ \\
\hline GAP (-1) & $\begin{array}{l}1.127 \\
(14.44)\end{array}$ & $\begin{array}{l}1.254 \\
(11.33)\end{array}$ & $\begin{array}{l}1.139 \\
(14.90)\end{array}$ & $\begin{array}{r}1.260 \\
(11.76)\end{array}$ & $\begin{array}{c}1.013 \\
(13.28)\end{array}$ & $\begin{array}{r}1.112 \\
(10.36)\end{array}$ & $\begin{array}{c}.982 \\
(12.53)\end{array}$ & $\begin{array}{l}1.050 \\
(9.62)\end{array}$ \\
\hline GAP (-2) & $\begin{array}{l}-.226 \\
(2.99)\end{array}$ & $\begin{array}{l}-.339 \\
(3.16)\end{array}$ & $\begin{array}{l}-.218 \\
(2.85)\end{array}$ & $\begin{array}{l}-.347 \\
(3.28)\end{array}$ & $\begin{array}{l}-.106 \\
(1.42)\end{array}$ & $\begin{array}{l}-.214 \\
(2.07)\end{array}$ & $\begin{array}{l}-.086 \\
(1.13)\end{array}$ & $\begin{array}{c}-.155 \\
(1.49)\end{array}$ \\
\hline Real rate $(-1)$ & $\begin{array}{l}-.086 \\
(2.88)\end{array}$ & $\begin{array}{l}-.001 \\
(.04)\end{array}$ & $\begin{array}{c}-.079 \\
(2.66)\end{array}$ & $\begin{array}{l}-.001 \\
(.15)\end{array}$ & $\begin{array}{l}-.081 \\
(2.91)\end{array}$ & $\begin{array}{l}-.118 \\
(2.46)\end{array}$ & $\begin{array}{l}-.087 \\
(3.12)\end{array}$ & $\begin{array}{l}-.158 \\
(2.80)\end{array}$ \\
\hline $\mathrm{M}(-1)$ & $\begin{array}{l}.040 \\
(2.06)\end{array}$ & $\begin{array}{l}.004 \\
(.18)\end{array}$ & $\begin{array}{l}.033 \\
(2.01)\end{array}$ & $\begin{array}{l}-.004 \\
(.28)\end{array}$ & $\begin{array}{l}.106 \\
(5.18)\end{array}$ & $\begin{array}{l}.099 \\
(3.47)\end{array}$ & $\begin{array}{l}.131 \\
(5.11)\end{array}$ & $\begin{array}{l}.081 \\
(3.96)\end{array}$ \\
\hline$m m(-1)$ & $\mathrm{n} / \mathrm{a}$ & $\mathrm{n} / \mathrm{a}$ & $\mathrm{n} / \mathrm{a}$ & $\mathrm{n} / \mathrm{a}$ & $\mathrm{n} / \mathrm{a}$ & $\mathrm{n} / \mathrm{a}$ & $\begin{array}{l}.102 \\
(4.96)\end{array}$ & $\begin{array}{l}.013 \\
(3.96)\end{array}$ \\
\hline Constant & $\begin{array}{l}.002 \\
(1.39)\end{array}$ & $\begin{array}{l}-.000 \\
(.00)\end{array}$ & $\begin{array}{c}.002 \\
(1.79)\end{array}$ & $\begin{array}{l}.0003 \\
(.23)\end{array}$ & $\begin{array}{l}-.001 \\
(.80)\end{array}$ & $\begin{array}{c}.002 \\
(1.32)\end{array}$ & $\begin{array}{l}-.001 \\
(1.12)\end{array}$ & $\begin{array}{l}.005 \\
(2.12)\end{array}$ \\
\hline$\overline{\mathrm{R}}^{2}$ & .91 & .94 & .91 & .94 & .92 & .95 & .92 & .94 \\
\hline $\mathrm{SE}$ & .007 & .005 & .008 & .005 & .007 & .005 & .007 & .004 \\
\hline DW & 2.10 & 2.27 & 2.06 & 2.29 & 2.05 & 2.21 & 2.26 & 2.12 \\
\hline $\mathrm{F}(\mathrm{pr})^{2}$ & .09 & & .00 & & .06 & & .17 & \\
\hline
\end{tabular}

1. See notes to Table 1

2. Probabilities for F-statistic based on 1982/IV break. 
